\title{
The teaching of Māori social work practice and theory to a predominantly Pākehā audience
}

\author{
Shayne Walker
}

Shayne Walker (Kai Tahu, Ngati Kahungunu) is a senior lecturer at the Department of Sociology, Gender and Social Work, University of Otago. He has a background in Maatua Whangai, youthwork, child protection and Māori social service organisations.

\begin{abstract}
This article will explore the practices of teaching social work students in Aotearoa New Zealand to equip them for bicultural practice. This includes te reo Māori (the Māori language) and tikanga (culture) papers as well as specific teaching on the Treaty of Waitangi provisions. It will discuss some of the results, which suggest students know about Treaty provisions but are less able to translate this knowledge into practices, which are bicultural. It then suggests some strategies for moving this teaching forward so that students start to feel accustomed to and confident in practices which are suited to a bicultural setting. In this, it is suggested that it might be necessary to take a cross-cultural position and take aspects from diversity or cross-cultural training to enhance students' understanding and ability in working with Māori in the South Island of Aotearoa New Zealand. One of the difficulties with taking this approach is that most of these models emerge from a western rather than an indigenous framework of understanding and practice. In using this work, it is attempted to integrate indigenous methods and worldviews.
\end{abstract}

\section{Introduction}

Māori in Aotearoa New Zealand today still occupy relatively disadvantaged positions (Statistics New Zealand, 2012), despite 30 years of the renewed application of a framework to try and redress the balance. The original Treaty of Waitangi of 1840 and its provisions were intended to provide both a constitutional basis and framework for a partnership between Pākehā and Māori in Aotearoa New Zealand - the nation was officially constituted as being based on two equal cultures in 'partnership' (Fleras and Spoonley, 1999). Since that time the provisions of the Treaty have been in abeyance until relatively recently, when the Māori renaissance and reassertion of their Treaty rights have forced them to be recognised and re-affirmed. Understandably there has been some resistance, with resurgence of Māori being seen as a matter of divisiveness and leading to resentment amongst some Pākehā (Fleras and Spoonley 1999). In my teaching and practice experience this resistance is predominately with the older generation. The younger generation in Aotearoa New Zealand is significantly less resistant than their elders and this is undoubtedly at least partly due to the changed education around the Treaty and its history in recent years. It has also become a significant, if variably implemented, requirement for professional education, especially the socially oriented people professions. The Aotearoa New Zealand Association of Social 
Workers (ANZASW) requires social workers to take responsibility for understanding a Te Tiriti o Waitangi-based society (2008) and the Social Workers Registration Board (SWRB) has also shown a commitment to Treaty-based education and practice. The first two standards for SWRB registration and competency relate to practice with Māori and cultural 'others' (SWRB 2012).

Thus in 2012 Treaty teaching is mandatory for social work students as a critically important issue, as social statistics show Māori to be over-represented in most of the negative indicators (Statistics New Zealand, 2012). As importantly, appropriate responses to working with and for Māori in a partnership authorised by the provisions of the Treaty are necessary to assist to counter the wider discriminatory attitudes towards Māori. However, in my region, Te Waipounamu, the South Island of New Zealand, we sought to assess the value of our programme especially since the low relative populations of Māori in the South Island may well lead social work students to believe that their work will not bring them so closely into contact with Māori as their North Island counterparts. A continued ascription to minority status thus might result. If people are going to work with Māori then they will have to learn how. The Treaty of Waitangi is positioned well within the theory and practice of human rights and social justice, but using the Treaty as a piece of moral blackmail to develop bicultural practice, as we may have tended to do in the past, is not the solution.

Students often ask Anaru Eketone and me to teach them Māori practice models i.e. Whare Tapa Whā, Poutama, etc but we are sometimes hesitant as they can be devoid of context in a university setting. The objectives for this article are to examine the dilemmas present in teaching in a bicultural context, as shown by research, and to suggest alternative strategies from my own teaching experiences. These may have relevance for other contexts in which educators are confronted with similar issues of educating social workers for practice with minority cultural groups and I especially invite discussion on methods others have found useful.

Further contemporary contextual issues for educators of Māori social work practice and theory are:

- Mandatory registration of social workers by the SWRB (SWRB, 2012).

- Whanau Ora goals: self managing, living healthy lifestyles, participating fully in society, confidently participating in te ao Māori, economically secure and successfully involved in wealth creation, cohesive, resilient and nurturing (Durie, Cooper, Grennell, Snively, \& Tuaine, 2010).

- Tribal development: cultural distinctiveness, economic benefits (Durie, 2012).

- The Green (2011) and White (2012) Papers for Vulnerable Children: partnerships, culturally tailored services, connecting to services, highlighting similarities, reducing barriers to services, social and economic factors (Ministry of Social Development, 2011, pp. 11-12).

- Capacity building of the workforce to meet the needs of whanau Mãori.

- Simple solutions of further surveillance as opposed to structural responses to poverty, health, housing and income maintenance.

The position advocated for in this paper supports social work education for Māori by Māori, especially in culturally specific service provision where a culturally specific knowledge base and skill set is absolutely necessary, i.e. Iwi Social Services. But what of non-Māori working 
with Māori and others in a variety of organisations? How do we prepare them for social work practice?

\section{Bicultural, cross-cultural and Treaty-based education at Otago}

In 2003 Dr Susan Young from the University of Western Australia was invited to undertake a research project with graduates of the professional social work programme of the University of Otago. She was interested in how the graduates translated bicultural or cross-cultural theory into daily practice; in particular what had helped and what were the barriers. She also explored what additional learning the graduates wanted (Young, 2003 in Walker, Walker, \& Eketone, 2006).

Practitioners acknowledged that both formal and informal forms of learning were important to their practice (Young, 2003). Formal learning through courses at university provided knowledge of Te Reo Māori (language) and Tikanga Māori (culture) and history. These courses gave students opportunities to learn the nature and values connected to critical reflection, the holistic approach of social work, an understanding of diversity and culture and the relation of this to the self; and the plethora of generic skills that are necessary to provide social work services in a broad variety of settings. Informal learning came through a variety of settings including secondary learning from peers and beyond the classroom into fieldwork placements where students come into contact with 'experiential learning' opportunities (Walker, Walker, \& Eketone, 2006).

Young (2003) discovered some evidence of a disjuncture between the 'knowing about' or being 'culturally literate' and 'being able to do' aspects of working with people from different cultures. Young's research found that graduates felt unprepared for bicultural and cross-cultural social work practice (Walker, Walker, \& Eketone, 2006).

The process of helping students get a point where they can translate what they have learnt about bicultural and cross-cultural practice in the classroom (academic) into reallife (relational) social work practice skills and methods is complex. However, I agree with Young's (2003) conclusion where she states;

It is the task of educators to capitalise on the opportunistic and design strategies to ensure all learners have the opportunity to learn using different strategies. What is significant here is the preparedness or the propensity for learning shown by some people's past experiences. How we as educators use these diverse situations and opportunities to assist students learn especially in the area of bicultural and cross-cultural practice is a challenge (Young, 2003, p. 3-4 in Walker, Walker, \& Eketone, 2006).

Learning from Young (2003) and feedback from Māori service providers, I have become more aware of the need to improve the teaching of bicultural and cross-cultural theories and practice. When students leave our programme they need to be confident with the complexities of working with the cultural 'other' while they find their own way to integrate their knowledge into practice without being overwhelmed by the challenges (Said 1978).

\section{Bicultural and cross-cultural education}

The SWRB and ANZASW require social work programmes in the Department of Sociology Gender and Social Work to be underpinned by the Treaty of Waitangi. This is a challenge 
due to the Treaty being an overarching document between two sovereign parties, which does not equate easily to better bicultural practice amongst social work students (Young 2003). Upon critical reflection I would argue that the current methods of teaching about bicultural or, in fact, cross-cultural practice will not lead to better understanding of micro (personal) or meso (organisational) levels of the subject. I have come to the position where I am convinced that Treaty-based practice (especially for non Māori) is best located within the wider discourse of cross-cultural practice.

For that reason I now utilise an approach by Perry and Tate-Manning (2006) who interpreted the cultural competency work of Finnish author Skutnabb-Kangas (1988). This approach provides a useful context for my Treaty teaching. I'm not saying that culture-specific training about specific ethnicities or whatever form the 'other' may take is not important. Perry and Tate-Manning (2006) outlined cultural competency as having three major elements, cognitive knowledge, affective competency and behavioural competency.

- Cognitive knowledge is viewed as information gathered from secondary sources such as books and movies, and usually does not challenge one's culture values.

- Affective competency is about identifying with aspects of another culture and being able to apply appropriate cultural norms in different situations. This involves being able to compare the 'other' culture from within one's own cultural identity.

- Behavioural competency requires internalisation of the 'other' cultural values and norms and being able to behave in an appropriate manner in a different settings. Conflict often arises when there are competing norms (Walker, Walker, \& Eketone, 2006).

Using Young's (2003) results to assess the Otago social work programme, the cognitive competency has been achieved. The students graduate from the programme with a good understanding of the Treaty of Waitangi, knowledge of history, the injustices perpetuated upon Māori and the subsequent results in highly negative statistics, basic knowledge of Te Reo Māori (language) and Tikanga Māori (culture). However, according to Young (2003) there is a failure to translate this knowledge and understanding into both affective and behavioural cultural competencies (Walker, Walker, \& Eketone, 2006).

Another useful model that may provide possible solutions is the 'Bennett Scale'. We have utilised the 'Developmental model of inter-cultural sensitivity' developed by Milton Bennett (1993). This is a systematic approach, to developing awareness of one's own attitudes and explores how people give meaning to cultural differences. It operates as a continuum of two states; ethno-centric and ethno-relative. Each state has three orientations: denial, defence/ reversal and minimisation, and acceptance integration and adaptation respectively. People move through these states and orientations as they acquire inter-cultural competence. The underlying assumption is that, as one's understanding of the experience of cultural difference becomes more complex, one's potential competence in intercultural relations increases. This approach may be a safe way for students to gain an understanding of their own position and 'isms' (Walker, Walker, \& Eketone, 2006).

\section{The Universty of Otago social work programme response.}

In Aotearoa New Zealand, which is a constitutionally bicultural nation where Māori and English forms are officially institutionalised, there is also a need for multicultural practice. 
Thus in both Skutnabb-Kangas' 'cognitive' competence and Bennett's 'ethno-centric' stage of development there are two steps required - recognition first of the Māori culture in the context of a bicultural nation and secondly the multicultural situation within the bicultural context with other non-Treaty cultures. Fleras and Spoonley (1999) refer to this as multiculturalism within a bi-national framework. Thus while, in what follows, I will be essentially discussing Treaty-based social work education and practice, such discussion is also necessary for the teaching of multicultural practice as well (Walker, Walker, \& Eketone, 2006).

In response to Young's (2003) research, the Otago social work programme is developing its teaching methods to reflect the best models of intellectual (cognitive) learning as well as role modelling expected behaviours, experiential learning and practicum experience.

As we have noted above, students initially require an intellectual journey, which is of greater significance than merely learning 'about' another culture. The challenge is to understand how to create theoretical pathways for students to have a safe place to question and debate their understandings of biculturalism and working with 'other' cultures. This raises the epistemological question: How are we thinking about our thinking? (Sewpaul, 2012). Sands and Nuccio (1992) would argue that students need intellectual space to be able to deconstruct the opposing discourses about the cultures of 'others'. This intellectual space also provides a logical pathway, which encourages them to move on from binary thinking and challenge the oppositional hierarchies that value or privilege one group over another. When students discover multiple discourses that are subjectively constructed, this can lead to a realisation that culture is contextually influenced, which is often multifaceted and contradictory (Walker, Walker, \& Eketone, 2006). Such realisation can be unsettling and decentring, but at the same time sets the scene for the analysis of power (Foucault, 1980) of who constructs the knowledge about the cultural or ethnic 'other' (Said, 1978).

Students are encouraged to examine their own values and attitudes and become 'not knowers', or humble experts. They are guests in Māori culture and are therefore 'kaitiaki' (guardians and stewards) not owners of the culture of the 'other'. An analysis of power is therefore critical (Dominelli, 2002; Beck \& Wahab, under review) otherwise cultural competence can easily become a form of 'new racism' (Pon, 2009) that can be used to disempower Māori.

We all have our particular construction of 'isms,' as Paul Haggis and Cathy Schulman's Oscar-winning (2006 best motion picture) film Crash illustrated. Are we challenging our own worldview or is this just something we believe others should do? For practitioners that work with those groups that have been reduced to an ascribed minority status the academic debate may move them from the 'put on smile' approach to a paternalistic bicultural and cross-cultural practice.

\section{Experiential learning: affective competency and 'ethno-relativity'.}

It is important for students and practitioners to become culturally competent with the cultural and ethnic 'other' they work with. The more students and practitioners are exposed and develop strong relationships with the cultural and ethnic 'other' the more competent they are likely to become. In my experience experiential (doing) activities such as te reo, tikanga and history were only relevant if they were associated with the right processes, 
settings and people, i.e. nohoanga marae (overnight marae stays) where learning is taking place in the same way they had been for a thousand years. The use of powhiri and mihi whakatau (Māori ritual of engagement) to bring them into this process often touches their hearts and their wairua (spirit). The practising of their own mihimihi (greeting) for the occasion is fraught with fear and nervousness, although no one has ever complained once they have done it. Staying on the marae is an experience in itself as they share the whare nui (large house usually for sleeping) with up to 60 others. All of these activities 'breathe life' into the university classroom learning and make it 'come alive' for some students. For some it's the beginning of a long-term relationship with their cultural other (Walker, Walker, \& Eketone, 2006).

The challenge is to get students and practitioners to relate these learning activities to working with Māori in their everyday work. Students regularly comment on how they absolutely enjoy getting to know the staff outside of a university classroom and see them 'walk their talk'. These activities are all organised 'in house' however and limited to one or two nights a year. Young (2003) found students value the experience however there is risk the experience is only cultural voyeurism and there are not ongoing and regular updates as part of a professional development programme (Walker, Walker, \& Eketone, 2006).

\section{Modelling: towards behavioural competence and ethno-relativity}

Co-teaching all the specifically Māori papers with a Māori colleague, Anaru Eketone, provides a number of advantages for the students. Students are often exposed for the first time to healthy debate about the diverse Maori community, including conflicting multi-tribal approaches to traditional and contemporary knowledge.

Anaru and I come from different professional backgrounds, with Anaru working in Māori organisations, while I have not. Our varied and sometimes oppositional professional backgrounds and skill bases complement one another, resulting in a much more consistent and deeper approach both in terms of practice and theory. We 'spark' off each other and encourage students' engagement in healthy debate about Maori approaches with us. If social work is the constructive and disciplined use of the self in relationships we must be the role models and socialise students to the thinking and behaviour we expect of them ( $\mathrm{O}^{\prime}$ Connor, Wilson, \& Setterlund, 2003, p. 53). We have a role as social workers, educators and researchers to be 'not knowers', that is humble experts who serve others. Remembering at all times 'the learning is in the relationship'.

Both Anaru and I have strong links into the local Māori community and both believe and pro-social model the necessity for good, strong, ongoing, hopefully accountable relationships. We have been trying to develop mentoring-style relationships with and for some students. Our hope is that the experiential learning previously mentioned in regards to Young's (2003) research can be 'cemented within a relationship,' because that is where a place of praxis can grow. This has cognisance with the 'tuakana and teina' relationship amongst Māori.

Mā te tuakana ka tōtika te teina, mā te teina ka tōtika te tuakana.

It is through the older sibling that the younger one learns the right way to do things and it is through the younger sibling that the older one learns to be tolerant. 
According to Arapera Royal Tangaere (Tangaere, 1997), the concept of tuakana/teina has emanated from two principles: whanaungatanga and ako ('learn, teach'). The tuakana/ teina relationship is a significant part of the dynamic of whanaungatanga, which is drawn from the importance of people particularly within the whānau, hapū and iwi. The idea of tuakana/ teina also operates through the dual nature of the term ako, which means to learn as well as to teach. You can be a teacher or a learner depending on the mahi and the kaupapa. This way of conceptualising the situation may actually free up all parties within the social work learning process because they become 'not knowers' and don't have to be experts. If we are prepared to do this in regards to any cultural or ethnic other, the opportunities to develop cross-cultural competencies that translate to all cultures increase because we realise there is real power in becoming a 'not knower.' This relationship can be created at a number of levels; at a micro level: personal network building and working relationships especially with whānau; at a meso level institution to institution; and at a macro level in terms of law and policy. At each of these levels different skills and knowledge bases and analytical frameworks for viewing may be necessary.

Unfortunately, the development of bicultural practice in Aotearoa New Zealand is still at such an emergent phase that the opportunities for all but a few students on practicum placements to fully grapple with and 'try out' their bicultural skills are limited. Students may be limited in their bicultural development because of the organisation's 'hard' or 'soft' commitment to bicultural goals, structures, policy and subsequent practice (Durie, 1995, 'Bicultural Continuum'). The fieldwork programme here at Otago cultivates bicultural practice through intensive, small-group weekly tutorials. This, however, is an area we hope to develop further as the knowledge and practice itself develops 'real world' practice situations.

We re-test the skills for Te Reo Māori (language) and Tikanga Māori (culture) in year 3 at a compulsory noho marae. Social work education provides a context for the viewing of and working with Maori but once they are in practice, the critical issue is 'how do they see Maori?', what kinds of lenses are students using to 'gaze' (Foucault, 1980) at Māori? Do they see 'distinctive' whanau who are 'theorists' and holders of 'capital'?

During my early education as a social worker I was challenged by the concept of conscientisation (Friere, 1972), anti-discriminatory approaches (Thompson, 1997, 2001) and anti-oppressive practice (Dominelli, 2002), But in 2010 I developed a synthesis that is 'trans-cultural' and seeks an understanding of the 'distinctiveness' (anōtanga) of tamariki and whānau based on their own 'meaning making frameworks' (Waldegrave, 2000). The logical link is 'strengths' based approaches (Saleeby, 2002, 2009), which are pragmatic in terms of practice outcomes. The latter part of Dennis Saleeby's 2002 book contains a set of questions that a practitioner can use to elicit strengths based responses; survival questions; support questions; exception questions - when things were going well, what was different?; possibility questions - what now do you want out of life?; esteem questions - when people say good things about you, what are they likely to say? The main premise for this synthesis is 'let's find out what is working in this whanau'. These questions are just tools to find out what is 'distinctive' (anō) about this whanau. The context speaks and has 'cues' within it i.e. whanau setting, use of te reo, tikanga, kawa, waiata, karakia, relationships, discipline, fun etc. There is a 'distinct' (anō) essence in each whanau and tamariki, and students must learn how to see it. 
In my teaching, I encourage students to view tamariki and whanau as 'theorists' (Walker, 2012), as they are the best historians of their own daily 'lived' experience. We may not agree with the narrative, but our initial role as practitioners is to listen and acknowledge their voices in a 'mana enhancing' (Ruwhiu, 2009) manner. This relates to tamariki and whanau-centred practice, in other words who will hear the voice of the tamariki and whanau, especially in the child protection process. For example, in the Family Group Conference (FGC) their voices and narrative compete with a number of other already privileged professional voices (McKenzie and Walker, 2007). There is a power/ knowledge equation (Foucault, 1980), where tamariki and whanau must have power attached to their voices and have the 'power to define' (Jackson, 1994). Subsequent to the sharing of power practitioners must have 'the skills to respect' i.e. te reo, knowledge of tikanga and kawa etc. As Khyla Russell (2000, p. 10) in her discussion on Native Theory states 'the right of indigenous people to make sense of their time and place in this world'. If not, tamariki and whanau become the 'other' (Said, 1978) and deficit-based thinking and action may emerge. Bob Marley's lyrics resonate we cannot change people, they have their own tino rangatiratanga:

Emancipate yourselves from mental slavery, none but ourselves can free our minds (Robert Nesta Marley).

I teach students to view tamariki and whanau as holders of 'capital' (MxKenzie, Omre, Schjelderup, Walker, \& Young, 2012), no matter how dysfunctional or negative the situation may appear. This is similar to Bourdieu's (1986) ideas of 'social, cultural, and symbolic capital'. I teach students that Tamariki and whanau capital has cognisance with Bourdieu's approaches, but it's not the same as it relates to whanau narratives and stories, survival and development strategies (Ruwhiu, 2009), whakapapa, whakatauki, waiata, organised whanaungatanga and traditions etc.

\section{Conclusion}

So, where to from here? Using materials from cross-cultural thinking can be seen as controversial especially with respect to the position of indigenous peoples in multicultural situations - when they may see themselves as diminished by it, as they so often are. Aotearoa New Zealand has a Treaty, which, in one sense is a protection against it. However, the history of ignoring that Treaty for almost 150 years indicates that it is not a panacea. This does not mean, however, that cross-cultural materials cannot be used - merely that they have to be used appropriately and in context.

Above all I want to stress that developing effective social work education in this area as in others is a dynamic process. We should all be aware that we occupy a position on this continuum and that position is influenced by personal and environmental factors. Cultural competency is very hard to measure - you can't judge it by looking at someone - it is an internalised process that has externalised outcomes. The learning we take from this model is that we should be training students and pro-social modelling as educators and practitioners, always asking the appropriate questions - learning to be the 'not knower'. This position forms the basis for many appropriate questions i.e. comings and goings, greetings, farewells, who should be in the room, the ascribed gender roles, the nature of the body and its parts, etc. (Walker, Walker, \& Eketone, 2006) 
In regards to Young's (2003) work and students being better prepared for bicultural and cross-cultural practice, we intend repeating the research within the next two years. We need to ascertain whether our approaches have quantifiably improved outcomes for students. In the meantime we will continue to develop new learning opportunities and strategies to avoid students potentially becoming paternalistic social workers who say to 'their' 'cultural and ethnic others on a regular basis' 'we can be equal as long as you'll be like me'. This article is not only intended as an overview of some aspects of our programme but also as a catalyst to create debate and learn new understandings and subsequent strategies in the process.

\section{Thank you for the opportunity to grow with you in this.}

'Where knowledge is gathered wisdom should follow'

\section{References}

ANZASW. (2008). Code of Ethics, second revision. Christchurch: Aotearoa New Zealand Association of Social Workers.

ANZASW. (1993). Code of Ethics and Bicultural Code of Practice. Auckland: Aotearoa New Zealand Association of Social Workers.

Beck, E, \& Wahab, S. (under review). Orientlaim in context for social work. Encyclopedia entry for the International Encyclopedia of social and behavioural sciences, 2nd ed. Elsevier Ltd.

Bennett, M. J. (1986). A developmental approach to training for intercultural sensitivity. International Journal of Intercultural Relations, 10, 179-196.

Bennett. M.J., (1993) Towards ethno relativism: A developmental model of intercultural sensitivity. In R.M. Paige (Ed.) Education for the intercultural experience, pp. 21-27. Yarmouth: Intercultural Press.

Bordieu, P. (1986). The forms of capital. In I. Szeman \& T. Kaposy, Cultural theory: An anthology (pp. 81-94). United Kingdom: Wiley-Blackwell.

Dominelli, L. (2002). Introducing anti-oppressive theories for practice. In Anti-oppressive social work: Theory and practice. Hampshire: Palgrave MacMmillan.

Durie, M. (1995). Beyond 1852: Maori, the State, and a New Zealand constitution. Sites, 30, 31-47.

Durie, M. (1998). Whaiora Maori Health Development, 2nd ed. Auckland: Oxford University Press.

Durie, M. (2012). Maori concepts of wellbeing: Intervening with Maori children, young people E families. Invercargill 20 July, Compass Seminars.

Durie, M., Cooper, L., Grennell, D., Snively, S., \& Tuaine, N. (2010). Whanau Ora: Report of the taskforce on whanaucentred initiatives. To: Hon Tariana Turia Minister for the Community and Voluntary Sector.

Eketone, A., \& Walker, S. (under review). Biculturalism as an approach to social work. Cross cultural social work: A critical reflective approach. Palgrave Macmillan.

Fleras, A., \& Spoonley, P. (1999). Recalling Aotearoa: Indigenous politics and ethnic relations in New Zealand. Auckland: Oxford University Press.

Fook, J. (2002). Social work: Critical theory and practice. London: Sage.

Foucault, M. (1980). Power/knowledge: Selected interviews and other writings 1972-1977. New York: Pantheon Books. Friere, P. (1972). The pedagogy of the oppressed. Middlesex: Penguin.

Hammer, M.R., Bennett, M.J., \& Wiseman, R. (2003). Measuring intercultural sensitivity: The intercultural development inventory. International Journal of Intercultural Relations, 27(4), 421-443.

Jackson, M. (1994). Community and Family Studies Hui. University of Otago.

Kelly, A., \& Sewell, A. (1988). With head, heart and hand: Dimensions of community building. Brisbane: Boolarong Publications.

McKenzie, M, Omre, C., Schjelderup, L., Walker, S., \& Young, S. (2012). Child rights/community development principles: Key elements for child protection practice. Joint World Conference on Social Work and Social Development: Action and Impact, 8-12 July 2012, Stockholm, Sweden.

McKenzie, M., \& Walker, S. (2007). Experiences and challenges of FGC in New Zealand: A view from New Zealand. In L. Schjelderup, \& C. Omre (Eds.) Veivisere for et fremtidig barnevern, p. 37-56. Trondheim: Taper Akademisk, Forlag.

Ministry of Social Development. (2011). The Green Paper for vulnerable children: Executive summary of submissions. Accessed from www.childrensactionplan.govt.nz. Wellington: New Zealand Government.

Ministry of Social Development. (2012). The White Paper for vulnerable children. Accessed from www.childrensactionplan.govt.nz. Wellington: New Zealand Government.

O'Connor, I., Wilson, J., \& Setterlund, D. (2003). Social work and welfare practice, 4th ed., pp.53-75. Sydney: Pearson Education Australia Pty Limited. 
Perry, C. \& Tate-Manning, L. (2006). Unravelling cultural constructions in Social work education: Journeying toward cultural competence. Social Work Education, 25(7), 735-748.

Pon, G. (2009). Cultural competence as new racism: An ontology of forgetting. Journal of Progressive Human Services, 20(1), 59-71.

Russell, K.J. (2000). Landscape: Perceptions of Kai Tahu. PhD thesis, University of Otago

Ruwhiu, L. (2009). Indigenous issues in Aotearoa New Zealand. In M. Connolly, \& L. Harms (Eds). Social work contexts and practice, pp. 107-120. Australia New Zealand: Oxford University Press.

Said, E. (1978). Orientalism. New York: Vintage Books.

Saleeby, D. (2002) The strengths perspective in social work practice, 3rd ed. University of Kansas. NY: Allyn \& Bacon.

Saleeby, D. (2009) The School of Social Welfare Lawrence Campus. The University of Kansas. Retrieved from http:/ / www.socwel.ku.edu/Strengths / faq.shtml.

Sands, R.G., Nuccio, K. (1992). Postmodern feminist theory and social work. Social Work Journal, 37(6), 489-94.

Sewpaul, V. (2012). Inscribed in our blood: Confronting the ideology of sexism and racism as possible seeds of liberation and radical change. Joint World Conference on Social Work and Social Development: Action and Impact, Stockholm, Sweden

Skutnabb-Kangas, T. (1988). Vahemmisto, Kieli ja Rasismi. Helsinki: Painokaari Oy.

Statistics New Zealand Tatauranga Aotearoa. (2012). Retrieved from http: / / www.stats.govt.nz/browse_for_stats / people_and_communities/maori/te-waharoa.aspx.

SWRB. (2012). Social Work Registration Board, Core Competence Standards. Retrieved from http:/ / www.swrb.govt. $\mathrm{nz} /$ competence-assessment/ core-competence-standards.

Tangaere, A. (1997). Maori human development learning theory. In P. Te Whaiti, M. McCarthy, \& A. Durie (Eds.), Mai i Rangiatea Maori wellbeing and development, pp. 46-59. Auckland University Press.

Thompson, N. (1997). The theory base in anti-discriminatory practice. London: Macmillan Press.

Thompson, N. (2001). Ethnicity and racism. In Anti-discriminatory practice, pp. 40-62, 3rd ed. Hampshire: Palgrave.

Waldegrave, C. (2000). 'Just Therapy' with Families and Communities. In G. Burford \& J. Hudson (eds.), Family group conferencing: New directions in community-centred child and family practice, pp. 153-164. New York: Aldine de Gruyter.

Walker, P. (2004). Partnership models within a Maori social-service provider. International Journal of Social Welfare, 13(2), 158-169.

Walker, R. (2004). Ka whawhai tonu matou: Struggle without end, 2nd ed. Auckland: Penguin Books.

Walker, S., Walker, P., \& Eketone, A. (2006). 'We can be equal as long as you'll be like me': Theory into practice: Biculturalism and social work practice (in a multicultural context). Presentation at the 33rd World Congress of The International Association of Schools of Social Work (IASSW).

Walker, S. (2012). Resiliency, child protection and Māori: A critical engagement. Joint World Conference on Social Work and Social Development: Action and Impact, 8-12 July 2012, Stockholm, Sweden.

Young. (2003). Opening new worlds: Stories from fields of bicultural and cross-cultural practice. University of Otago: Department of Community and Family Studies. 